\title{
Melatonin ve Antioksidan Etkileri
}

\author{
Nurhayat ATASOY ${ }^{1}$
}

\begin{abstract}
ÖZ
Çok eski zamanlardan beri varlığı bilinmesine rağmen pineal bezden salgılanan temel hormon olan melatoninin biyosentezi ve kimyasal yapısı ancak 1958 'de Lerner tarafindan ortaya konulabilmiştir. Melatonin gece boyunca en yüksek konsantrasyonda organizmada karşılaşılan sirkadiyen düzenleme ve uyku kontrolünden sorumludur. Kanda sirkadiyen bir ritim gösterir, gece değerleri ise gündüz seviyelerinden oldukça yüksektir. Melatoninin diğer önemli fonksiyonunun son derece güçlü serbest bir radikal temizleyici olduğu düşünülmektedir. Melatonin hem reaktif oksijen türlerini hem de reaktif azot türlerini etkisiz hale getirebilir. Melatoninin aynı zamanda çok toksik olan hidroksil radikalini, peroksi nitrit anyonu ve peroksil radikalini yakaladığı bilinmektedir. Melatonin bazı yerlerde bir prooksidatif enzim olan nitrik oksit sentetazı da inhibe etmektedir. Ayrıca süperoksit dismutaz enzimi için mRNA düzeyini sitümüle etmekte ve glutatyon peroksidaz, glutatyon redüktaz ve glukoz-6 fosfat dehidrojenazı aktive ettiği de bilinmektedir. Derlemenin amacı hem in vivo hem de in vitro yapılan deneyler sonucunda melatoninin çok güçlü bir antioksidan olduğunun önemini bir kez daha vurgulamaktır.
\end{abstract}

Anahtar Kelimeler: Melatonin; antioksidan; serbest radikal; fotoperiyodizm; uyku.

\section{Melatonin and Antioxidant Effects}

\begin{abstract}
Biosynthesis and chemical structure of melatonin, the main hormone secreted from the pineal gland, although its existence has been known since ancient times it appeared in 1958 by Lerner. Melatonin is responsible for circadian regulation and sleep control in the organism at the highest concentration throughout the night. In blood shows a circadian rhythm and night values are much higher than day levels. The other important function of melatonin is thought to be a strong free radical scavenger at extreme level. Melatonin can extinguish both reactive oxygen species and reactive nitrogen species. It is known that melatonin also catches the very toxic hydroxyl radical, peroxy nitrite anion and peroxyl radical. Melatonin also inhibits nitric oxide synthetase, a prooxidative enzyme in some places. It is also known that for the superoxide dismutase enzyme, also stimulate the mRNA level for the superoxide dismutase enzyme and glucose- 6 phosphate dehydrogenase are activated. The aim of the review is to emphasize once again the importance that melatonin is a very powerful antioxidant as a result of both in vivo and in vitro experiments.
\end{abstract}

Keywords: Melatonin; antioxidant; free radical; photoperiodism; sleep.

\section{Gíis}

Antioksidanlar insan vücudunda ve gıdalarda serbest radikallerin olumsuz etkilerini durduran veya yok eden maddelerdir. Antioksidan takviyesi ve antioksidanca zengin bir beslenme ile serbest radikallerin ve aktif oksijenin meydana getirdiği oksidatif hasar engellenebilmektedir $(1,2)$. Oksidatif stresin prooksidan tarafinda yer alan serbest oksijen radikalleri (SOR), fizyolojik olan ve olmayan birçok süreçte oluşmakta ve oksijenin hem süperoksit $\left(\mathrm{O}_{2}{ }^{-}{ }^{-}\right.$), hidroksil (HO), hidroperoksi $\left(\mathrm{HO}_{2}{ }^{\circ}\right)$, peroksi (ROO'), alkoksi (RO) gibi radikal türevlerini hem de singlet oksijen $\left(\mathrm{O}_{2}\right)$, ozon $\left(\mathrm{O}_{3}\right)$, hidrojen peroksit $\left(\mathrm{H}_{2} \mathrm{O}_{2}\right)$, hipoklorik asit $(\mathrm{HOCl})$, nitrik oksit (NO) ve peroksinitrit ( $\left.\mathrm{ONOO}^{-}\right)$gibi radikal olmayan türevlerini kapsamaktadır (1). Reaktif oksijen türlerinin (ROS) oluşumu enflamasyon, radyasyon, yaşlanma, normalden yüksek parsiyel oksijen basıncı $\left(\mathrm{pO}_{2}\right)$, ozon $\left(\mathrm{O}_{3}\right)$ ve azot dioksit $\left(\mathrm{NO}_{2}{ }^{\circ}\right)$, kimyasal maddeler ve 
ilaçlar gibi bazı uyarıların etkisiyle artar. Serbest radikaller hücrelerin lipid, protein, DNA, karbonhidrat ve enzim gibi tüm önemli bileşiklerine etki ederler. Süperoksit radikali $\left(\mathrm{O}_{2} \cdot{ }^{-}\right)$ve hidroksil radikali $\left(\mathrm{OH}^{*}\right)$ sitoplazma, mitokondri, nükleus ve endoplazmik retikulum membranlarında lipid peroksidasyonunu başlatır. Membranlarda lipid peroksidasyonu meydana gelmesi sonucu membran permeabilitesi artar (2).

Serbest radikallerin etkisiyle proteinlerdeki sistein sülfhidril grupları ve diğer amino asit kalıntıları okside olarak yıkılır, nükleer ve mitokondriyal DNA okside olur (3). Serbest oksijen radikallerinin tüm bu etkilerinin sonucunda hücre hasarı olur. Hücrede reaktif oksijen türlerinin (ROS) ve serbest radikallerin artışı hücre hasarının önemli bir nedenidir. İskemi sonrasında reperfüzyon da reaktif oksijen türlerinin (ROS) artışına bağlı olarak iskeminin oluşturduğu hücre hasarını artırır. Serbest oksijen radikallerinin neden olduğu hücre hasarının birçok kronik hastalığın komplikasyonlarına katkıda bulunduğu düşünülmektedir (4). Aterogenez, amfizem/bronşit, parkinson hastalığ 1 , duchenne tipi musküler distrofi, gebelik preeklampsisi, serviks kanseri, alkolik karaciğer hastalığı, hemodiyaliz hastaları, diabetes mellitus, akut renal yetmezlik, down sendromu, yaşlanma, retrolental fibroplazi, serebrovasküler bozukluklar, iskemi/reperfüzyon injürisi gibi durumlarda serbest oksijen radikallerinin neden olduğu hücre hasarı söz konusudur (3-5).

Reaktif oksijen türlerinin (ROS) oluşumunu ve bunların meydana getirdiği hasarı önlemek için birçok savunma mekanizmaları vardır. $\mathrm{Bu}$ mekanizmalar "antioksidan savunma sistemleri" veya kisaca "antioksidanlar" olarak bilinirler $(6,7)$. Antioksidanlar dört ayrı şekilde etki ederler. 1) Serbest oksijen radikallerini etkileyerek onları tutma veya daha zayıf yeni moleküle çevirebilirler. Antioksidan enzimler, trakeobronşiyal mukus ve küçük moleküller bu tip etki gösterirler. 2) Serbest oksijen radikalleriyle etkileşip onlara bir hidrojen aktararak aktivitelerini azaltma veya inaktif şekle dönüştürmede etkiye sahiptirler. Vitaminler, flavanoidler bu tarz bir etkiye sahiptirler. 3) Serbest oksijen radikallerini bağlayarak zincirlerini kırıp fonksiyonlarını engelleyici etki gösterirler. Hemoglobin, seruloplazmin ve mineraller zincir kırıcı etki gösterirler (8-10). Antioksidanlar, endojen kaynaklı veya eksojen kaynaklı olabilirler.

\section{Eksojen Antioksidanlar}

Eksojen antioksidanlar, vitaminler, ilaçlar ve gıda antioksidanları olmak üzere sinıflandırılabilirler. Alfatokoferol (vitamin E), $\beta$-karoten, Askorbik asit (vitamin C), Folik asit (folat) vitamin olan eksojen antioksidanlardır (10). Ksantin oksidaz inhibitörleri (allopürinol, oksipürinol, pterin aldehit, tungsten), NADPH oksidaz inhibitörleri (adenozin, lokal anestezikler, kalsiyum kanal blokerleri, nonsteroid antiinflamatuvar ilaçlar, diphenyline iodonium), Rekombinant süperoksit dismutaz, Trolox-C (vitamin E analoğu), Endojen antioksidan aktiviteyi artıranlar (GSHPx aktivitesini artıran ebselen ve asetilsistein), Nonenzimatik serbest radikal toplayicilar (mannitol, albümin), Demir redoks döngüsü inhibitörleri (desferroksamin), Nötrofil adezyon inhibitörleri,Sitokinler (TNF ve IL-1), Barbitüratlar,
Demir şelatörleri ise ilaç olarak kullanılan eksojen antioksidanlardır (11). Butylated hydroxytoluene (BHT), Butylated hydroxyanisole (BHA), Sodium benzoate, Ethoxyquin, Propylgalate, Fesuperoxyde dismutase ise gida antioksidanlarıdır $(10,11)$.

\section{Endojen Antioksidanlar}

Endojen antioksidanlar, enzim ve enzim olmayanlar olarak sinıflandırılır. Süperoksit dismutaz (SOD), Glutatyon peroksidaz (GSH-Px), Glutatyon STransferazlar (GST), Katalaz (CAT), Mitokondriyal sitokrom oksidaz sistemi, Hidroperoksidaz ise enzim olan antioksidanlardır. Melatonin, Seruloplazmin, Transferrin, Miyoglobin, Hemoglobin, Ferritin, Bilirubin, Glutatyon, Sistein, Metiyonin, Ürat, Laktoferrin, Albümin ise enzim olmayan antioksidanlardır. Diğer taraftan, hiperoksi durumu, iskemi, inflamasyon, ağır egzersiz, aromatik hidrokarbonlar, antineoplastik ajanlar, antibiyotikler, anestezikler, radyasyon, sigara dumanı ve hava kirliliği gibi çevresel faktörler ya direk olarak ya da intraselüler metabolizma ve detoksifikasyon sirasinda radikallere dönüşerek, Serbest oksijen radikali (SOR) düzeylerini etkilemektedirler (5).

\section{Melatonin}

Melatonin hormonunu ilk kez 1958 yılında Lerner tarafindan keşfedildi. Hipofizden elde ettiği bu hormonun cilt rengini açmasından dolayı bu maddeye, Latince siyah anlamına gelen "melas" ve iş anlamına gelen "tosos" kelimelerini birleştirerek "melatonin” adını verdi $(12,13)$.

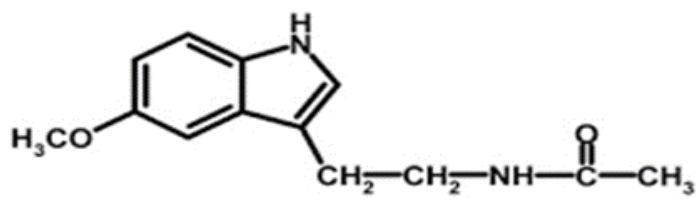

Şekil 1. Melatonin (N-acetyl-5-methoxytryptamine)

$\mathrm{N}$-asetil 5-metoksi triptamin olarak da bilinen melatonin hormonu pineal bezden salgılanan ve karanlıkta salgısının arttığ1 bilinen melatonin hormonu, güçlü antioksidan olmakla birlikte, hücrelerin yenilenmesi, bağışıklık siteminin güçlenmesi, uyku ritminin ve vücut 1sısının düzenlenmesi de diğer önemli görevleri arasındadır (14, Şekil 1). Melatonin salınımındaki sirkadyen ritm yaşla birlikte düzensizleşir. Sadece fizyolojik koşullarda değil duygudurum bozuklukları gibi bir takım klinik bozukluklarda da melatoninin sirkadiyen ritminin bozulmuş olması önem arz eder. Pineal bez, adını çam kozalağına benzeyen şeklinden almıştır. Beyin orta hattında, üçüncü ventrikülün arkasında yer almakta; 100150 mg ağırlıkta, 5-10 x 3-5 mm konik yapılı olup, insan vücudundaki en küçük endokrin bez olarak tanımlanır. Kan-beyin bariyeri içermeyen pineal bez, 4 ml/dk/g kan akımıyla böbreklerden sonra damarsal yapıdan da en zengin dokudur $(11,12,14)$. Yapısinda bulunan pinealositler sadece melatonin değil, serotonin, norepinefrin, histamin, dopamin gibi biyolojik aminleri; Luteinising hormone releasing hormone (LHRH), Tiroid stimüle edici hormon (TRH), somatostatin, arginin, vazopressin gibi peptidleri de sentezleyebilmektedir (12). 3. aya kadar nöroglial hücreler baskın iken daha sonra 
pinealositler artmaya başlayıp, \%95'inde baskın hale gelir (13). Melatoninin pineal bezden başka lakrimal bez, retina, eritrositler, trombositler ve gastrointestinal sistemdeki bazı hücrelerin de melatonin sentezlediği gösterilmiş olmasına rağmen bu sentezin plazma melatonin düzeyine etkisi çok azdır (14). Melatonin doğal bir nörotransmitterdir. Vücutta birçok biyolojik ve fizyolojik düzenlemelerde görev alır. İnsan biyoritimi (sirkadiyen ritim) üzerine etkili bir hormondur. Ana görevi vücudun biyolojik saatini koruyup ritmini ayarlamaktır. Hücrelerimizi yenileyici, bağışıklık sistemini düzenleyici, vücudumuzun biyolojik ritmini ayarlayıcı, anti-oksidan, yaşlanmayı geciktirici özellikleri olan melatonin hormonu gece salgılandığı için "karanlıklar hormonu" olarak da bilinir. Büyüme hormonunu arttırıcı ve ergenliği başlatıcı özellikleri de vardir (15-17).

\section{Melatonin sentezi}

Melatonin hormonunun ana maddesi triptofandır. $\mathrm{Bu}$ madde önce serotonine dönüşür. Melatonin pinealositlerde triptofandan sentezlenir. Melatonin sentezinde temel biyomolekül, triptofan amino asitidir. Triptofan, triptofan hidroksilaz enzimi tarafindan 5hidroksitriptofona çevrilir. 5-hidroksitriptofan, aminoasit dekorbaksilazla serotonine; serotonin, N-asetil transferazla $\mathrm{N}$-asetil serotonine; $\mathrm{N}$-asetil serotonin de metiltransferaz enzimi aracılığı ile melatonine dönüştürülmektedir (13). Triptofan hidroksilaz enzimi, tetrahidrobiopterin $\left(\mathrm{BH}_{4}\right)$ ve $\mathrm{O}_{2}$ 'yi kofaktör olarak kullanır. Yine buradaki reaksiyonda $\mathrm{B}_{6}$ vitamini koenzim olarak görev yapmaktadır (18).

Serotonin ve melatonin sentezinde görev yapan ve ara metabolit olan 5-hidroksitriptofan, kan-beyin bariyerini rahatlıkla aşabilir $(19,20)$. 5-hidroksitriptofan, 5hidroksitriptamine (serotonin) dönüştüğü zaman kanbeyin bariyerini geçebilme özelliğini ortadan kalkar. Mutluluk ve enerji veren serotonin ise hava kararmaya başlayınca melatonine dönüşür (19). Akşam hava karardıktan sonra, gözdeki fotoreseptörlerden mesaj gelir ve saat 19.00-20.00 civarında melatonin salgisı artmaya başlar, gece 02.00-04.00 arasında en yüksek noktasına ulaşır, sabah gün 1şı̆̆ının artmasıyla salgısı azalır. Sabah 07.00-09.00 arasında ise azalmaya başlar. Salgılanma hızı 29 mg/gün'dür $(11,20)$.

Melatonin hormon salgısı kışın uzun gecelerde daha fazla, yazın daha az salgılanır. Jet lag denilen olayın nedeni de bu hormondur. Yapılan çalışmalarda gece görev yapan insanların daha çabuk hastalandığı ve kanser hastalığına yakalanma risklerinin daha çok olduğu bulunmuştur (21).

2.Melatonin Sentez ve Salınımına Etki Eden Faktörler Melatoninin sentezi ve salınmasını etkileyen birçok faktör olsa da en önemli faktör 1şıktır. Yani aydınlıkkaranlık; gündüz-gece ritmi sentez ve salınımın düzenlenmesini kontrol eder. $\mathrm{Bu}$ düzenleme mekanizması, “fotonöroendokrin kontrol” olarak tanımlanmıştır. Pineal melatonin sentezindeki sirkadiyen ritmin sekronizasyonunun yanı sıra 1şık, melatonin sentezini de akut olarak baskılayabilir. Özellikle 1 şık şiddeti melatoninin baskılanma düzeyinin ölçülmesinde önemlidir ve 1şık uyaranının parlaklığı arttıkça, baskılama gücü de artış gösterir (22-24). Deney hayvanlarında yapılan bir çalışmada, gece süresinde uygulanan loş beyaz 1şı̆̆ın $\left(0.037 \mathrm{PW} / \mathrm{cm}^{2}\right)$ pineal melatonin seviyesinde; daha yüksek şiddetteki $\left(0.074 \mathrm{mikroW} / \mathrm{cm}^{2}\right)$ 1şığın 20 dakika uygulanmasının melatonin seviyesinde \%40-50'lik bir azalmaya neden olduğu; 1şık şiddeti iyice arttığında ise (0.111-1.86 mikroW/cm²) \%80-95'lik bir azalmaya neden olduğu gösterilmiştir (9). Işığın melatonin sentezi üzerine etkisi, dalga boyu ve şiddeti ile yakın ilişkilidir. Serum melatonin düzeyi, yaşa göre değişmektedir. Yeni doğanda kan melatonin düzeyi düşüktür. Üçüncü aydan sonra melatonin düzeyi ritmik özelliğini kazanır. Melatonin anne sütüne geçebildiğinden anne sütü ile beslenen bebeklerin diğer yollarla beslenen çocuklara göre sirkadiyen organizasyonları daha çabuk gelişir. Alkol, sigara, fazla kahve ve çay, 1 şı, ses, yatmadan önce karnın tok olması, depresyon ilaçları, uyku ilaçları ve beta blokerler de melatonin salgılanmasını yavaşlatır (21-26).

\section{Melatonin Reseptörleri}

Melatonin, hedef dokularda bulunan özgül reseptörleri vasıtasıyla etkisini gösterir. Vücutta retina, beyin, hipofiz başta olmak üzere dalak, eritrosit, lökosit, tiroid bezi, timus, plasenta, endometrium ve gastrointestinal sistem gibi periferal dokuların çoğunda da reseptörlerin bulunduğu bildirilmiştir (16). Farmakolojik olarak memelilerde hücre zarına bağlı MT1 (yüksek afiniteli) ve MT2 (düşük afiniteli) olmak üzere iki farklı melatonin reseptörü bildirilmektedir. Hormona özgü reseptörler hücredeki etkinliğini $\mathrm{G}$ proteini aracılığıyla gerçekleştirir. MT1 reseptörleri başlica hipotalamusun suprakiyazmatik çekirdeğinde tespit edilirken, MT2 reseptörleri retina, hipokampus ve diğer beyin bölgelerinde belirlenmiştir (27). Melatonin reseptörleri ayrıca mide-bağırsak kanalı, gonadlar, böbrek ve kan damarlarında da bulunur. İmmun fonksiyonun güçlenmesinde MT2 reseptörünün önemli rol oynadığı bildirilmektedir (28-30).

\section{Melatoninin Antioksidan Etkisi}

Melatonin'in bir antioksidan olduğu, literatürde ilk kez 1991 yilında Ianas ve ark. (31) tarafından öne sürülmüş ve daha sonra yapılan in vitro ve in vivo çalışmalarla desteklenmiştir. Antioksidanlar etki mekanizmalarını serbest radikalleri tutarak veya daha zayıf yeni bir moleküle çevirerek, serbest radikalle etkileşip aktivitelerini azaltarak, serbest radikalleri kendilerine bağlayıp reaksiyon zincirini kırarak ya da onarım yaparak gösterirler. Melatonin'in antioksidan özelliği, yapısında bulunan pirol halkasından kaynaklanmaktadır. Oksidatif doku hasarına yol açan bazı toksinlerle oluşan oksidatif stres melatonin tarafindan önlenir. Melatonin, bu serbest radikal toplayıcı özelliği için bağlanma bölgesine ve reseptöre gereksinim duymaz (32).

Melatonin hem suda hem de lipid fazda çözünebildiğinden tüm intraselüler komponentlere rahatlıkla geçip hücre zarını, organelleri ve çekirdeği etkin bir şekilde serbest radikal hasarından korumaktadır. Melatonin çeşitli yönleriyle klasik antioksidanlardan (E vitamini, C vitamini, b-karoten vs.) farklıdır. Ayrıca redoks döngüsüne ve radikal üreten reaksiyonlara girmez. Klasik antioksidanlar etkilerini gösterdikten sonra prooksidan maddelere dönüşürler. Melatonin'in bazı prooksidan enzimleri inhibe ederek, serbest radikal oluşumunu azalttığ 1 ve bu yolla da antioksidan sistemi desteklediği öne sürülmektedir (27). Oksidatif stres olarak tanımlanan prooksidanlar (sies), ateroskleroz, 
respiratuvar distres sendromu, diyabet, kronik böbrek yetmezliği, sepsis, romatoid artrit, ve alzheimer hastalığ gibi birçok patolojik durumda, hatta yaşlilıkta ortaya çıkmaktadır (33-35).

Ratlara, akut/kronik uygulanan melatonin'in beyin dokusu Mn-SOD ve Cu-Zn-SOD sentezini artırdığı ve bu yolla oksidatif hasara karşı ratlarda yapılan deneylerde anne karnındaki fetus beyninde SOD aktivitesini artırdığ 1 gösterilmiştir $(35,36)$. Kolaylıkla kan-beyin bariyerini ve plasentayı geçebilen melatonin için, melatonin'in tüm intraselüler komponentlere rahatlikla ulaşabilmesini sağlamaktadır (29,30). Böylece melatonin, hücre zarını, organelleri ve çekirdeği etkin bir şekilde serbest radikal hasarından koruyabilmektedir. Hücre membranı ile temas ettiğinde, fosfolipid tabakasının dış yüzeyine tutunan melatonin, radikallerle membrandan önce temasa geçerek onları detoksifiye eder ve membranı korur. Melatonin varlığında, mitokondriyal solunum zincirinden kaynaklanan oksijen $\left(\mathrm{O}_{2}\right)$, hidroksil (HO) gibi radikallerin ve hidrojen peroksitin $\left(\mathrm{H}_{2} \mathrm{O}_{2}\right)$ üretimi de azalmaktadır. Çekirdeğe kadar ulaşabilme özelliği, DNA'nın oksidatif hasara karşı korunmasında, melatonin'e bir üstünlük sağlamaktadır. Yüksek lipofilik ve hidrofilik özelliğe sahip melatonin, vücutta depolanmadan kan ve vücut sıvılarına hızla karışır (31). Melatonin büyük ölçüde karaciğerde hidroksilasyonla (6hidroksimelatonin) hızla metabolize olur ve sülfürik ya da glukuronik asit ile konjuge olduktan sonra idrarla atılır. Melatonin idrardaki başlica metaboliti 6sülfatoksimelatoninin düzeyi serum melatonin düzeyi ile yakın ilişkilidir. Gece idrarındaki 6-sülfatoksimelatonin gece melatonin sentez miktarını yansitır. Melatonin, böbreklerde de metabolize olur (37).

Son yıllarda, endojen savunma sistemini güçlendirmek amaciyla, organizmada doğal olarak bulunan savunma sistemlerinin bir kısmı ya da antioksidan özellik gösteren bazı farmakolojik ajanlar da kullanılmakta ve bu bileşikler, ekzojen savunma sistemleri olarak adlandırılmaktadır. $\mathrm{Bu}$ grup arasında, Süperoksit dismutaz (SOD), askorbat, glutatyon (GSH) ve melatonin (3) sayılabilir. Melatonin en zararlı serbest radikal olan hidroksil serbest radikalini $\left(\mathrm{OH}^{\circ}\right)$ ortadan kaldıran çok güçlü bir antioksidandır, günümüze kadar bilinen antioksidanların en güçlüsü olarak kabul edilmektedir. Melatonin hidroksil serbest radikali $\left(\mathrm{OH}^{*}\right)$ ile reaksiyona girdikten sonra bir indolil katyon radikaline dönüşür ki bunun da ortamdaki süperoksit radikalini $\left(\mathrm{O}_{2}{ }^{-}\right)$tutarak antioksidan aktivite gösterdiği kaydedilmiştir (2).

Melatoninin antioksidan olarak diğer bir özelliği lipofilik olmasıdır, hücrenin hemen bütün organallerine ve hücre çekirdeğine ulaşabilir ve böylece çok geniş bir dağılımda antioksidan aktivite gösterir. Serbest oksijen radikalleri oluşturmak suretiyle kansere sebep olan safrolün DNA üzerine hasar oluşturucu etkisinin, melatonin tarafindan çok etkili şekilde inhibe edildiği gösterilmiştir. Melatonin kanserin ilerleme ve gelişme safhalarını geciktirir. Yaşlanma ile birlikte pineal bezin fonksiyonları ve melatonin düzeyi azalırken, beraberinde antioksidan kapasitenin azalmasına bağlı olarak yaşlanma ile ilgili hastalıklarda artmaktadır $(38,39)$.

Melatonin'in bu antioksidanlardan daha güçlü olduğu (28), glutatyon (GSH)'dan 5 kat ve mannitolden 14 kat daha güçlü bir şekilde $\mathrm{OH}^{*}$ radikalini yakaladığı (19) in vitro çalışmalarla gösterilmiştir. Farmakolojik ve muhtemelen fizyolojik düzeylerdeki Melatonin'in, Süperoksit dismutaz (SOD), glutatyon peroksidaz (GSHPx), glutatyon redüktaz (GSSG-Rd), glukoz-6-fosfat dehidrogenaz (G6PD) ve g-glutamilsistein sentetaz gibi bazı antioksidan enzimlerin gen ekspresyonlarını ya da aktivitelerini artırdığı ve bu yolla oksidatif stresi baskıladığı bildirilmektedir. Antioksidan savunma sistemi ile ilişkili diğer bir enzim sitokrom P450 enzimidir. Bu enzim ksenobiyotik metabolizması aracılığı ile serbest radikal oluşumunu artırır. Melatonin'in P450 aktivitesini azaltarak serbest radikal oluşumunu ve dolayısı ile oksidatif hasarı azalttığı gösterilmiştir (16).

Melatonin, radikallerle membrandan önce temasa geçerek onlar1 detoksifiye eder ve membranı korur. Melatonin varlığında, mitokondriyal solunum zincirinden kaynaklanan $\mathrm{O}_{2}{ }^{\circ}$, $\mathrm{HO}$ gibi radikallerin ve $\mathrm{H}_{2} \mathrm{O}_{2}$ üretimi de azalmaktadır. Çekirdeğe kadar ulaşabilme özelliği, DNA'nın oksidatif hasara karşı korunmasında, melatonin'e bir üstünlük sağlamaktadır (6). Daha da önemlisi, diğer antioksidanların aksine, çok yüksek dozlarda (300 mg/gün) ve 5 yıl gibi uzun süre kullanımda bile, melatonin'in toksik bir etki göstermemesidir (40). Melatonin'in antioksidan etkileri genel olarak incelendiğinde, adezyon moleküllerinin ve proinflamatuvar sitokinlerin sentezini azaltmasını da içeren oldukça geniş spektruma sahip bir antioksidan olduğu görülebilir $(6,41)$.

Gece 1ş1ğa maruz kalan kişilerde melatonin düzeyleri düşük olup meme kanseri riski yüksektir. Meme kanser riski kortizol ile de ilişkili olup gün içinde ve akşam saatlerinde yüksek kortizol meme kanser riskini artırır (42). Ayrıca endometrium, prostat, akciğer, gastrik ve kolon kanserlerinde melatonin düzeylerin düşük olduğu buna karşılık melatoninin antioksidan etkileriyle de kansere karşı koruyucu olabileceği bildirilmiştir (5). Melatonin, protein ve lipitlerin yanı sıra hem çekirdek DNA'sını hem de mitokondriyel DNA'yı korur. Kısacası Melatonin, doğrudan bir serbest radikal süpürücüsü ve dolaylı bir antioksidan olarak her yerde faaliyet göstermesi sayesinde çok geniş çaplı bir koruma sağlar (43). Böylece melatonin hidroksil radikali, hidrojen peroksit, singlet oksijen, nitrik oksit, peroksinitrit anyonu ve peroksinitrik asit içeren reaktif türleri ve serbest radikallerin farklı formlarını temizler. Bunlara ek olarak, Süperoksit dismutaz (SOD), katalaz (CAT), glutatyon peroksidaz (GPx) ve glutatyon redüktaz (GR) içeren antioksidan enzimlerin bazılarını da uyarır (43-45).

\section{SONUÇ VE ÖNERILER}

Günümüzde serbest radikallerin kanser, kardiyovasküler ve nörodejeneratif hastalıklar, yaşlanmadaki etkileri başta olmak üzere antioksidan kullanımını ortaya çıkarmış ve bu konudaki çalışmalar giderek önem kazanmıştır. Melatonin diğer birçok antioksidan ile karşılaştırıldığında, gerek güçlü radikal süpürücü etkisi ve gerekse antioksidan enzim aktivitelerini artırıcı etkisi ile önem kazanmıştır. Ancak melatoninin klinikte uygulanabilmesi için çalışmalar devam etmektedir. Birçok antioksidanın karşılaştırıldığı çalışmalardan ortaya çıkan sonuç, melatoninin en güçlü antioksidanlardan biri olduğunun ispatlanmasıdır. 


\section{KAYNAKLAR}

1. Karabulut H, Gülay MŞ. Antioksidanlar. MAE Vet Fak Derg. 2016; 1(1): 65-76.

2. Sies H. Oxidative stress: Oxidants and antioxidants. Exp Physiol. 1997; 2(2): 291-5.

3. Lobo V, Patil A, Phatak A, Chandra N. Free radicals, antioxidants and functional foods: Impact on human health. Pharmacogn Rev. 2010; 4(8): 118-26.

4. Ramis MR, Esteban S, Miralles A, Tan DX, Reiter RJ. Protective effects of melatonin and mitochondriatarget antioxidants against oxidative stress: A review. Curr Med Chem. 2015; 22(22): 2690-711.

5. Atasoy ÖB, Erbaş O. Melatonin hormonunun fizyolojik etkileri. FNG \& Bilim Tıp Dergisi. 2017; 3(1): 52-62.

6. Reiter RJ, Calvo JR, Karbownik M, Qi W, Tan DX. Melatonin and its relation to the immune system and inflammation. Ann NY Acad Sci. 2000; 917: 376-86.

7. Konturek SJ, Konturek PC, Brzozowska I, Pawlik M, Sliwowski Z, Cześnikiewicz-Guzik M. Localization and biological activities of melatonin in intact and diseased gastrointestinal tract (GIT). J Physiol Pharmacol. 2007; 58(3): 381-405.

8. Johns JR, Latts JA. Theoretical insight into the antioxidant properties of melatonin and derivatives. Org. Biomol. Chem. 2014; 12(39): 7820-7.

9. Yellon SM. Acute $60 \mathrm{~Hz}$ magnetic field exposure effects on the melatonin rhythm in the pineal gland and circulation of the adult Djungarian hamster. J Pineal Res. 1994; 16(3): 136-44.

10. Dusak A. Kolon kanserli hastalarda bazı antioksidant enzim aktivitelerinin incelenmesi [Yüksek Lisans Tezi]. Van: Van Yüzüncü Yıl Üniversitesi Fen bilimleri Enstitüsü; 2015.

11. Sen S, Chakraborty R. The Role of Antioxidants in Human Health. In: Andreescu S, Hepel M, editors. Oxidative Stress: Diagnostics, Prevention, and Therapy; 2011. p. 1-37.

12. Hilton G. Melatonin and the pineal gland. Journal of Neuroscience Nursing. 2002; 34(2): 74-8.

13. Beyer CE, Steketee JD, Saphier D. Antioxidant properties of melatonin-an emerging mystery. Biochem Pharmacol. 1998; 56(10): 1265-72.

14. Claustrat B, Brun J, Chazot G. The basic physiology and pathophisology of melatonin. Sleep Med Rev. 2005; 9(1): 11-24.

15. Reiter RJ. The mammalian pineal gland: Structure and function. Am J Anat.1981; 162(4): 287-313

16. Yilmaz B. Epifiz (Pineal bez). Hormonlar ve üreme fizyolojisi. Ankara: Feryal Matbaacilık; 1999.

17. Yazıcı C, Köse K. Melatonin: Karanlığın antioksidan gücü. Erciyes Üniversitesi Sağlık Bilimleri Dergisi. 2004; 13(2): 56-65.

18. Brzezinski A. Melatonin in humans. N Engl J Med. 1997; 336(3): 186-95.

19. Maksimovich AA. Structure and function of the pineal gland in the vertebrates. Zh Evol Biokhim Fiziol. 2002; 38(1): 3-13.

20. Hardeland R, Pandi-Perumal S, Cardinali DP. Melatonin. Int J Biochem Cell Biol. 2006; 38(3): 3136.

21. Gomes P, Soares-da-Silva P. L-DOPA transport properties in an immortalised cell line of rat capillary cerebral endothelial cells, RBE 4. Brain Res. 1999; 829(1-2): 143-50.

22. Reiter RJ, Tan DX, Manchester LC, Simopoulos AP, Maldonado MD, Flores LJ, et al. Melatonin in edible plants (phytomelatonin): Identification, concentrations, bioavailability and proposed functions. World Rev Nutr Diet. 2007; 97: 211-30.

23. Özcelik F, Erdem M, Bolu A, Gülsün M. Melatonin: General Features and its Role in Psychiatric Disorders, Current Approaches in Psychiatry. 2013; 5(2): 179-203.

24. Scheer F, Czeisler CA. Melatonin, sleep, and circadian rhythms. Sleep Med Rev. 2005; 9(1): 5-9.

25. Şener G. Karanlığın hormonu: Melatonin. Marmara Eczacılık Dergisi. 2010; 14(3): 112-20.

26. Ferguson SA, Rajaratnam SM, Dawson D. Melatonin agonists and insomnia. Expert Rev Neurother. 2010; 10(2): 305-18.

27. Pandi-Perumal SR, Trakht I, Srinivasan V, Spence DW, Maestroni GJ, Zisapel N, et al. Physiological effects of melatonin: role of melatonin receptors and signal transduction pathways. Prog Neurobiol. 2008; 85(3): 335-53.

28. Liu J, Clough SJ, Hutchinson AJ, Adamah-Biassi EB, Popovska-Gorevski M, Dubocovich ML. MT1 and MT2 Melatonin Receptors: A Therapeutic Perspective. Annu Rev Pharmacol Toxicol. 2016; 56: 361-83.

29. Emet M, Ozcan H, Ozel L, Yayla M, Halici Z, Hacimuftuoglu A. A Review of Melatonin, Its Receptors and Drugs. Eurasian J Med. 2016; 48(2): 135-41.

30. Çetin E. Melatonin ve Bağışıklık Sistemi. J Fac Vet Med Univ Erciyes. 2005; 2(2): 119-23.

31. Ianas O, Olivescu R, Badescu I. Melatonin involvement in oxidative processes. Rom J Endocrinol. 1991; 29(3-4): 147-53.

32. Reiter RJ. Functional aspects of the pineal hormone melatonin in combating cell and tissue damage induced by free radicals. Eur J Endocrinol. 1996; 134(4): 412-20.

33. Reiter RJ, Maestroni JM. Melatonin in relation to the antioxidative defense and immune systems: Possible implications for cell and organ transplantation. J Mol Med. 1999; 77(1): 36-9.

34. Karaaslan Ç, Suzen S. Antioxidant properties of melatonin and its potential action in diseases. Current Topics in Medicinal Chemistry. 2015; 15(9): 894-903.

35. Miller E, Morel A, Saso L, Saluk J. Melatonin redox activity. Its potential clinical applications in neurodegenerative disorders. Curr Top Med Chem. 2015; 15(2): 163-9.

36. Kotler M, Rodriguez C, Sainz R, Antolin I, Menendez-Pelaez A. Melatonin increases gene expression for antioxidant enzymes in rat brain cortex. J Pineal Res. 1998; 24(2): 83-9.

37. Reiter RJ. The pineal gland and melatonin relation to aging: A summary of the theories and of the data. Exp Gerontol. 1995; 30(3-4):199-212.

38. Vriend J, Reiter RJ. Melatonin feedback on clock genes: a theory involving the proteasome. J Pineal Res. 2015; 58(1): 1-11. 
39. Hardeland R. Melatonin in aging and disease multiple consequences of reduced secretion, options and limits of treatment. Aging Dis. 2012; 3(2): 194225.

40. Sanchez A, Colpena AC, Clares B. Evaluating the oxidative stress in inflammation: Role of melatonin. Int J Mol Sci. 2015; 16(8): 16981-7004.

41. Johns JR, Latts JA. Theoretical insight into the antioxidant properties of melatonin and derivatives. Org. Biomol. Chem. 2014; 12(39): 7820-7.

42. Hill SM, Belancio VP, Dauchy RT, Xiang S, Brimer S, Mao L, et al. Melatonin: An inhibitor of breast cancer. Endocr Relat Cancer. 2015; 22(3): R183-204.

43. Yücel GN, Kaplanoğlu GT, Seymen C M. Karanlığın Mucizesi: Melatonin ve ovaryum etkileşimi. Dicle Tip Dergisi / Dicle Med J. 2018; 45(1): 85-92.

44. Kuznetsova TY, Solovyova NV, Solovyov VV, Kostenko VO. Antioxidant activity of melatonin and glutathione interacting with hydroxyland superoxide anion radicals. Ukr. Biochem. J. 2017; 89(6): 22-30.

45. Manchester LC, Coto-Montes A, Boga JA, Andersen LP, Zhou Z, Galano A, et al. Melatonin: An ancient molecule that makes oxygen metabolicall tolerable. J Pineal Res. 2015; 59(4): 403-19. 